\title{
The Effect of a Tutorial Programme Using Interactive Video on the Aspects of Learning Some Gymnastics Skills Within Deaf and Dumb Pupils
}

\section{*Dr/ Reda Saad Yassen}

\section{Introduction and research} problem:

Progress in any environment or society is measured by the extent to which it takes care of its children in general and those with needs (disabilities) in particular. So that this individual becomes a useful member of the society in which he lives.

Hearing Impairment is considered one of the sensory impairments, which ranges from very severe hearing impairment to mild hearing impairment, which leads to impossibility of speech and lack of understanding of spoken speech (Wotout and Sawwaf, 2013, p. 44.)

There is no doubt that hearing and sight are among the most important tools of education, which is what the Great Creator, may $\mathrm{He}$ be glorified and exalted, has decided in his saying Surah AlNahl, Verse No. (78). God
Almighty has blessed the individual with a group of senses to help him perceive and understand what surrounds him and what is going on around him. When the individual loses the sense of hearing. The greater reliance on the sense of sight becomes in education and the delivery of information, as well as the interest in all methods of visual learning (Abd al-Ghaffar, 2003, pp. 7, 8)

There is no doubt that the aspiration to prepare a useful member of society and a generation capable of developing and developing society can only be achieved through an advanced educational system that carries with it all individuals (students) who are normal or have special needs. Among those with special needs, there is the group of the hearingimpaired individual who is able to learn and even succeed if he is well instructive and instructive (Muhammad, Atallah, 2003, p. 1)

Assistant Professor of Gymnastics, Department of Gymnastics, Exercise, Kinetic Expression and Sports Shows, Faculty of Physical Education - Tanta University. 


\section{1}

The

modern

technological revolution has become an important input in the teaching and learning processes. The era in which we live is also characterized by practical application. And the teacher became incumbent upon him to be constantly renewed and to use suggested strategies in order to improve the educational process and make learners more effective and responsive,

Which leads to the speed of learning at anytime and anywhere and with less effort and taking into account individual differences between learners and getting out of the rigid stereotypes, whether that is the normal or For people with special needs (Mahmoud and Mahrous, 2002, p. 10)

The minds of physical education scientists and researchers have tended to search for the employment of educational technology in delivering information to the handicapped of all groups, and to provide various technological means, methods and methods of teaching.

They found that the interactive video is one of the innovations used to present knowledge and information. And through it, the image is displayed through a display that works as an integrated unit. It consists of a computer and an input device for pictures, drawings and information (Mazen, 2009, p. 44.) Interactive video can display and present information in many forms, as it is presented using video clips. And the fixed frames with their accompanying texts and drawings for the presentation (Abdel-Hamid, 2010, pp. 169, 170.)

Whereas, special education schools "deaf and hard of hearing" represent one of the educational institutions that bear the responsibility for educating the disabled in a balanced and integrated education in all aspects so that they produce an individual who is able to give and be positive within the society in which he lives,

And the physical education subject is one of the Curriculum materials assigned to them within those institutions, and gymnastics subject is one of the basic sports which, upon learning, requires the use of modern and effective teaching methods commensurate with the characteristics of hearingimpaired students. Looking at previous and similar studies on 
the hearing impaired, such as Fen Stermenster (2001), Cardener, Daveid (2003).

Mahmoud (2005),

Browmson et al (2007), Nazmi (2008), Al-Thaqafi (2012), and Al-Fathli (2013). These studies have shown great progress in the teaching techniques used with this group, which led to an increase in their level of performance.

In this regard, it must be noted that the handicapped child is hearing like any normal child who has his physical, psychological and social needs and needs to meet these needs in a way that helps him to be on par with the normal child (Choucair, 2005, p. 131)

The teaching profession is not easy in the field of educating the ordinary (normal), and the matter becomes more difficult in the field of the hearing impaired. The deaf child needs a special quality of treatment. The relevant aids are one of the necessary requirements that help the handicapped in general and the hearing impaired in particular to learn the skills of various sports activities, as well as to raise their level of skill performance by relying on their visual sense by presenting more clear examples of the skills to be learned (Abd al-Ghaffar, 2003, p.112)

Gymnastics is one of the basic sports within the physical education class for the hearingimpaired curriculum and the skills taught within it are skills that require a great deal of fitness.

Gymnastics is one of the sports that aims to develop the body in an integrated development through exercises that are performed on different devices that have a special character. These exercises may be simple or complex, which requires the use of codified programs to complete the educational process (Shehata, 2003, p. 12)

Also, performance in gymnastics is done on multiple devices, including the ground movement's device, which has a special nature of performance that requires different physical and

psychological characteristics. Therefore, this sport is of special importance (Shehata and Abd al-Salam, 1991, p. 50)

And performance on the device of ground movements in gymnastics gains the learner (strength, flexibility, ability, agility, motor rhythm, balance, compatibility of the muscular 
and nervous systems). It also affects the psychological aspect, whereby the learner gains a sense of contentment and a sense of beauty through the performance of a motor sentence or through the completion of extremely difficult skills (Shehata and Abd al-Salam, 1991, p. 51)

All or some of these skills are taught to female students in private schools, and thus we seek to provide them with various aspects of learning through physical education programs in general and gymnastics activity in particular.

And through the researcher's acquaintance with previous studies, and through frequent visits to a special education school. For the deaf and dumb in Shebin Al-Kom "and by asking those in charge of the educational process (teachers) and the school board of directors for the 2015/2016 academic year about teaching that category,

It was found that learning basic skills within the physical education class, including some gymnastics skills, as one of the basic sports. By explaining on his part through sign language and finger spelling and showing a model of the skill without actual participation on the part of the learner in the educational situation, which negatively affects the practice of that sport and those skills.

And that no technological methods are used with that group. Despite the scientific progress we have reached. And whoever has reached that category in the use of Mobil or other electronic devices that contain among its files a file addressing the deaf and mute through the signal roll.

Through the above and the researcher's attempt to keep pace with scientific and technological progress, and through a comprehensive survey of the characteristics and requirements of that category, the researcher will conduct a study entitled "The effect of an educational program using interactive video on aspects of learning some gymnastics skills for deaf and dumb students".

\section{Research goal:}

The research aims to design an educational program using interactive video and its effect on learning some gymnastics skills for deaf and dumb pupils, through which: 
1-Changing the traditional teacher's role and making him design educational environments.

$r$-Making use of technology in educating this group.

r-Take advantage of the means, images and graphics through interactive video to facilitate the delivery and presentation of skills.

$\varepsilon$-Show some gymnastics skills in an interesting, attractive and easy way.

Research hypotheses:

o-There are statistically significant hypotheses between the mean of the pre and post measurements of the experimental group in the level of skill performance and cognitive attainment of the skills under investigation in favor of the post measurement.

7 -There are statistically significant differences between the averages of the pre and post measurements of the control group in the level of skill performance and the cognitive achievement of the skills under investigation in favor of the post measurement.

V-There are statistically significant differences between the two dimensional measures of the experimental and control group in both the level of skill performance and the cognitive achievement in favor of the experimental group.

$\wedge$-There are statistically significant differences between the pre and post measurements of the experimental group towards the use of the interactive video tutorial in learning the skills under investigation in favor of the post measurement.

\section{Search terms:}

\section{Interactive video:}

It is a video program that is divided into small parts consisting of motion sequences, fixed frames, questions and lists, while the learner's responses through the computer are the determinants of the number of sequence watching the video, and accordingly the shape and nature of the presentation will be affected (Ali, 2009, pp. 316, 317)

\section{Deaf:}

It is the individual who lost the sense of hearing for reasons. As for hereditary, innate, or acquired, whether from birth or afterwards, which prevents him from continuing his studies and learning life experiences with his ordinary peers by regular means, and therefore he needs rehabilitation that fits his sensory limitations (Abdel-Al, 2007, p. 14).

\section{The dumbest:}


$\mathrm{He}$ is the child who lost his hearing ability in the first three years of his life and as a result he could not acquire the language or speech (Al-Shitati, 2005, p.10)

Search procedures:

Research Methodology:

The researcher used the experimental method using two groups, one experimental and the other controlling, following the pre and post measurement, due to its relevance to the nature of the study.

\section{Community and Sample Research:}

The research community represents the eighth grade pupils of elementary school at Al-Amal School for the Deaf and Dumb in Menoufia Governorate for the academic year (2016-2017) in Shebin alKom, whose number is (28) male and female students, and the researcher selected a sample of (20) male and female students from the total research and study community. .

An experimental group consisting of (10) male and female students to apply the educational program used (interactive video) and a control group of (10) male and female students who apply the traditional method used in learning skills. Where the teacher explains in sign language and finger spelling and displays a sample of skill only. (8) students have been excluded due to the disparity in age, lack of regularity in attendance and lack of commitment to sports performance, and the exploratory sample represents students of the eighth grade of elementary school at Al-Amal School for the Deaf and Dumb in the academic year (20162017), and the researcher deliberately selected the sample (20) male and female students out of the total community of 25 male and female students, in order to bring the students closer to the level of chronological, mental, economic and social age and the availability of assistants, tools and playgrounds.

\section{Moderation and equivalence of the research sample:}

To calculate the equivalence of the research, the researcher set the same variables affecting the research, namely:

Chronological age. Body height. - mental capacities.

-Physical variables related to the skills in question (handstand skill - handstand skill "rolling on the chest and abdomen" - handstand skill "forward rolling", according to what was shown by the study of Ismail and others (2006), Abdel Shakour and Roshdy (2009) Muhammad and Hijazi (2011)

The strength of the two men is the speed. Fixed balance in reverse conditions. -Carrying strength for the arms. Shoulder Force (Stretchy.) 
Flexibility of the spine. - The transition speed.

As well as the level of skill performance of the skills under discussion (handstand skill, handstand skill "rolling on the chest and abdomen", handstand skill "roll forward."
The researcher used to find the homogeneity and parity between the sample members, the torsion coefficient to indicate the moderation of the data, as shown in Table $(1,2)$

Table (1)

Statistical significance of characterizing both experimental and control groups in the basic variables to demonstrate the moderation of the data $N=20$

\begin{tabular}{|c|c|c|c|c|c|c|c|}
\hline $\mathbf{S}$ & Variables & $\begin{array}{c}\text { Measure } \\
\text { unit }\end{array}$ & SMA & Mediator & $\begin{array}{l}\text { Standard } \\
\text { deviation }\end{array}$ & Flatulence & skewers \\
\hline \multicolumn{8}{|c|}{ Significant growth rates } \\
\hline 1 & Age & Year/month & 13.855 & 14.000 & 0.315 & 2.183 & -1.641 \\
\hline$r$ & Height & $\mathrm{Cm}$ & 154.600 & 154.500 & 3.604 & -1.401 & 0.039 \\
\hline$r$ & Weight & $\mathrm{Kg}$ & 49.050 & 49.000 & 2.564 & 0.525 & 0.729 \\
\hline$\varepsilon$ & \begin{tabular}{|l|}
$\begin{array}{l}\text { Intelligence } \\
\text { (mental abilities) }\end{array}$ \\
\end{tabular} & Degree & 87.100 & 89.000 & 5.990 & -1.371 & -0.132 \\
\hline \multicolumn{8}{|c|}{ Physical exams } \\
\hline 1 & \begin{tabular}{|l|} 
The power of \\
speed for the feet
\end{tabular} \mid & $\mathrm{Cm}$ & 159.800 & 160.000 & 5.105 & 0.217 & -0.119 \\
\hline $\bar{r}$ & Static balance & $S$ & 47.050 & 49.000 & 4.947 & -0.652 & 0.022 \\
\hline r & $\begin{array}{l}\begin{array}{l}\text { Withstand the } \\
\text { strength of } \\
\text { arms }\end{array} \\
\text { the }\end{array}$ & No & 19.000 & 19.500 & 2.128 & -0.570 & -0.547 \\
\hline$\varepsilon$ & \begin{tabular}{|l|} 
Measurement of \\
shoulder velocity \\
force
\end{tabular} & No & 33.400 & 34.000 & 3.016 & -0.230 & 0.097 \\
\hline 0 & \begin{tabular}{|l|}
$\begin{array}{l}\text { Flexibility of the } \\
\text { spine and trunk }\end{array}$ \\
\end{tabular} & $\mathrm{Cm}$ & 2.825 & 2.750 & 0.345 & -0.570 & 0.587 \\
\hline 1. & Transition speed & $\mathrm{S}$ & 10.695 & 10.400 & 0.749 & 1.625 & 1.241 \\
\hline \multicolumn{8}{|c|}{ The form of skill performance } \\
\hline$T$ & Handstand skill & Degree & 1.175 & 1.000 & 0.568 & -0.002 & 0.652 \\
\hline r & $\begin{array}{l}\text { Handstand } \\
\text { rolling on chest } \\
\text { and abdomen }\end{array}$ & Degree & 1.025 & 1.000 & 0.499 & -0.585 & 0.596 \\
\hline$r$ & $\begin{array}{l}\text { Handstand, roll } \\
\text { in front }\end{array}$ & Degree & 1.125 & 1.000 & 0.358 & -0.826 & -0.418 \\
\hline 1 & $\begin{array}{l}\begin{array}{l}\text { Cognitive } \\
\text { achievement test }\end{array} \\
\end{array}$ & Degree & 0.950 & 1.000 & 0.647 & -0.828 & 0.204 \\
\hline \multicolumn{8}{|c|}{$\begin{array}{l}\text { Table (1) shows the } \\
\text { arithmetic mean, median, } \\
\text { standard deviation, and torsion } \\
\text { coefficient of both groups of } \\
\text { the research sample in the basic }\end{array}$} \\
\hline
\end{tabular}


the values of the torsion coefficient ranged between $( \pm$ 3), which gives a direct indication of the absence of defects in the data Nonequilibrium distributions.

\section{Table (2)}

Homogeneity and significance of differences between the mean of the pre measurements in the experimental and control groups In the basic variables under investigation to demonstrate equivalence $N 1=n 2=10$

\begin{tabular}{|c|c|c|c|c|c|c|c|c|c|c|}
\hline \multirow[t]{2}{*}{$S$} & \multirow{2}{*}{ Variables } & \multirow{2}{*}{$\begin{array}{l}\text { Measure } \\
\text { unit }\end{array}$} & \multicolumn{2}{|c|}{\begin{tabular}{|c|}
$\begin{array}{c}\text { Experimental } \\
\text { group }\end{array}$ \\
\end{tabular}} & \multicolumn{2}{|c|}{$\begin{array}{l}\text { Control } \\
\text { group }\end{array}$} & \multirow{2}{*}{\begin{tabular}{|c|} 
The \\
difference \\
between \\
the \\
averages \\
\end{tabular}} & \multirow[t]{2}{*}{ Homogeneity } & \multirow{2}{*}{$\begin{array}{c}\text { Value } \\
(\mathrm{v})\end{array}$} & \multirow{2}{*}{$\begin{array}{c}\text { The level of } \\
\text { statistical } \\
\text { significance } \\
\end{array}$} \\
\hline & & & $\mathrm{S}$ & $\pm \mathrm{E}$ & $\mathrm{S}$ & $\pm \mathrm{E}$ & & & & \\
\hline \multicolumn{11}{|c|}{$\overline{\text { Significant growth rates: }}$} \\
\hline 1 & Age & Year/month & 13.870 & 0.298 & 13.840 & 0.347 & 0.030 & 1.353 & 0.207 & 0.838 \\
\hline$r$ & Height & $\mathrm{Cm}$ & 155.100 & 3.573 & 154.100 & 3.755 & 1.000 & 1.104 & 0.610 & 0.549 \\
\hline$r$ & Weight & $\mathrm{Kg}$ & 49.900 & 2.807 & 48.200 & 2.098 & 1.700 & 1.790 & 1.534 & 0.144 \\
\hline$\varepsilon$ & $\begin{array}{l}\text { Intelligence } \\
\text { (mental abilities) }\end{array}$ & Degree & 86.900 & 5.607 & 87.300 & 6.651 & 0.400 & 1.407 & 0.145 & 0.886 \\
\hline \multicolumn{11}{|c|}{ Physical exams: } \\
\hline 1 & $\begin{array}{l}\begin{array}{l}\text { The power of } \\
\text { speed for the feet }\end{array} \\
\end{array}$ & $\mathrm{Cm}$ & 159.700 & 5.056 & 159.900 & 5.425 & 0.200 & 1.151 & 0.085 & 0.933 \\
\hline$r$ & Static balance & S & 47.400 & 4.949 & 46.700 & 5.187 & 0.700 & 1.098 & 0.309 & 0.761 \\
\hline$r$ & $\begin{array}{l}\text { Withstand the } \\
\text { strength of } \\
\text { the arms }\end{array}$ & No & 19.300 & 2.111 & 18.700 & 2.214 & 0.600 & 1.100 & 0.620 & 0.543 \\
\hline$\varepsilon$ & $\begin{array}{l}\text { Measurement } \\
\text { of shoulder } \\
\text { velocity force }\end{array}$ & No & 34.000 & 2.828 & 32.800 & 3.225 & 1.200 & 1.300 & 0.885 & 0.388 \\
\hline 0 & $\begin{array}{l}\text { Flexibility of } \\
\text { the spine and } \\
\text { trunk }\end{array}$ & $\mathrm{Cm}$ & 2.800 & 0.362 & 2.850 & 0.344 & 0.050 & 1.108 & 0.317 & 0.755 \\
\hline 7 & $\begin{array}{l}\text { Transition } \\
\text { speed }\end{array}$ & $S$ & 10.630 & 0.615 & 10.760 & 0.893 & 0.130 & 2.112 & 0.379 & 0.710 \\
\hline \multicolumn{11}{|c|}{ Form of skill performance: } \\
\hline 1 & \begin{tabular}{|l} 
Handstand \\
skill
\end{tabular} & Degree & 1.150 & 0.626 & 1.200 & 0.537 & 0.050 & 1.356 & 0.192 & 0.850 \\
\hline$r$ & $\begin{array}{l}\text { Handstand } \\
\text { rolling on } \\
\text { chest and } \\
\text { abdomen }\end{array}$ & Degree & 1.050 & 0.599 & 1.000 & 0.408 & 0.050 & 2.150 & 0.218 & 0.830 \\
\hline$r$ & $\begin{array}{l}\text { Handstand, } \\
\text { roll in front }\end{array}$ & Degree & 1.150 & 0.337 & 1.100 & 0.394 & 0.050 & 1.367 & 0.305 & 0.764 \\
\hline 1 & $\begin{array}{l}\text { Cognitive } \\
\text { achievement } \\
\text { test }\end{array}$ & Degree & 0.900 & 0.658 & 1.000 & 0.667 & -0.100 & 1.026 & 0.338 & 0.740 \\
\hline
\end{tabular}

Tabular (q) value at 0.05 level of significance and two degrees of freedom $(9,9)=3.18$

Tabular ( $\mathrm{t}$ ) value at $0.05=2.101$ level of significance

Table (2) shows that the value of the largest variance over the smaller variance in all the variables is less than the tabular value of $(\mathrm{P})$ at the level of significance 0.05, which 
indicates the homogeneity of the two research groups. It is also clear that there are no statistically significant differences between the premeasurements of the experimental and control groups in the basic variables. Under discussion, which gives a direct indication of the equivalence of the two groups in these variables?

\section{Methods of data collection:}

Search Forms. Stringer (1)

Growth rate (chronological age - height - weight). Accessory (1)

Mental abilities (intelligence). Accessory (2)

Tests used to measure the physical variables associated with the skills under investigation. Accessory (3)

Cognitive achievement test. Accessory (4)

1-Tests to assess the level of skill performance of the skills under discussion. Accessory (5)

A questionnaire of opinions and emotional impressions towards the educational program. Extension (6)

\section{1- Research forms:}

An expert opinion survey form to determine the most important physical abilities related to gymnastics skills under discussion and it included (6) physical abilities that were extracted from previous studies and references (specialized) Shenouda and Farghali (1999), Ismail (2006),
Yassin (2008), Abdel Shakour and Roshdy (2009) ),

Muhammad and Hijazi (2011), and it was presented to (5) five experts who have a Ph.D. degree in Appendix (7). The experts agreed that they are related to the skills under study, where the expert expresses his opinion by placing a mark () in front of the appropriate physical ability for the skill With the possibility of adding any other physical ability, the researcher selected the physical abilities that obtained $(80 \%)$ or more from the opinions of experts, and thus a number of (6) physical abilities related to the gymnastics skills under discussion were obtained, Annex (3.)

$r$-Personal data registration form: Appendix (1)

-The name.

- Age - Height - Weight.

-The degree of hearing from the reality of records in the school.

-Score of physical tests of the skills in question.

\section{3- Mental Abilities}

(Intelligence): Appendix (2)

The researcher used the nonverbal intelligence test prepared by Fayza Makrami, which was translated by Farouk Abdel Fattah - where the test includes three parts (A, $\mathrm{B}$, and $\mathrm{C}$ ) and includes eleven paragraphs of difficulty and the first part (A) is used to determine the general level of the individual in mental 
functions and the part is used The second (b, c) in improving and confirming the prediction of the mental level of the individual and we find that each part begins with the presentation of the easy paragraphs after the student has answered some difficult paragraphs in the previous part and this test is one of the typical tests suitable for the category of deaf and dumb students, and this test was used in Many studies, as in the study of Al-Najjar and Atallah (2003)

Mahmoud (2012), Abdel Hamid (2014) Scientific Transactions to Test Mental Abilities (Intelligence)

ᄉ-Suggested educational program: Annex (8)

Steps to prepare the tutorial included the following:

Teaching some gymnastics skills for deaf and dumb pupils through the interactive video method and knowing its effect on aspects of learning performance (skill - cognitive emotional)

-The skill aspect:

That the students perform the correct performance of some gymnastic skills and that they can understand the correct motor path

The knowledge aspect: for the students to get acquainted with the most important technical and basic points of the skills under discussion.

The emotional aspect: that the students acquire positive attitudes, a sense of happiness and a habit of observation during the performance.

\section{$r$-Basis for setting up the program:}

-That the content of the program fit the target of the program.

-That the program takes into account the characteristics of the students.

The program should take into account individual differences and be up to their abilities.

Provide the right place to perform while giving everyone the opportunity to practice.

-Take into account the suspense, gradual and motivation.

-That the program (the software) be characterized by simplicity, clarity, diversity, and the satisfaction of the learners' need for activity and movement.

$r$-Defining the general framework of the program:

The researcher set up (12) study units at the rate of two units per week and the unit time (45 minutes) for a period of 6 weeks. The expert opinions were represented in the best time to watch the program immediately before the warm-up and based on the above, the time distribution of the parts of the study unit for the experimental group became as follows: 
Table (2)

The time distribution of the unit parts of the experimental group

\begin{tabular}{l|l|l}
\hline \hline Unit parts & \multicolumn{1}{|c|}{ Content } & Time \\
\hline \hline $\begin{array}{l}\text { administrative } \\
\text { works }\end{array}$ & Greeting and absence registration & $2 \mathrm{~m}$ \\
\hline $\begin{array}{l}\text { Watch } \\
\text { programs }\end{array}$ & $\begin{array}{l}\text { Interact with the software in the skills section } \\
\text { separately }\end{array}$ & $10 \mathrm{~m}$ \\
\hline Warm up & $\begin{array}{l}\text { Body-shaping and prepping exercises or free } \\
\text { warm-up and stations }\end{array}$ & $5 \mathrm{~m}$ \\
\hline $\begin{array}{l}\text { Public and physical } \\
\text { private paration } \\
\text { preparits }\end{array}$ & $\begin{array}{l}\text { Development of fitness components for each } \\
\text { skill under investigation }\end{array}$ & $10 \mathrm{~m}$ \\
\hline $\begin{array}{l}\text { Basic and } \\
\text { applied activity }\end{array}$ & $\begin{array}{l}\text { Pupils apply what they have seen in the teaching media } \\
\text { room, under the supervision and direction of the school }\end{array}$ & $10 \mathrm{~m}$ \\
\hline $\begin{array}{l}\text { The closing } \\
\text { part }\end{array}$ & $\begin{array}{l}\text { Calming exercises to return to normal. Greetings } \\
\text { and leave }\end{array}$ & $3 \mathrm{~m}$ \\
\hline \hline
\end{tabular}

4- Organizing the program content (software:)

The educational software prepared in the interactive video style is the goal of this research, which was prepared by the software engineer by means of (Visual Basic6) program, which is a program used in preparing educational software based on the use of the computer and includes the stages of preparing the educational program:

1- Building educational software:

(stages)

A- Design phase (Design)

-It is like a map for the software based on (scientific educational - technical)

-And that the scientific material be presented in a logical manner and a behavioral formulation that is appropriate to the age of the students

And to present the scientific material in a logical and sequential manner.

-And to make use of the screen space by organizing it to reach the best texts that explain the theoretical part and the skills under study. A set of static and moving images was obtained through the Photo Shop (CS8) program and writing on it.

-Then the introduction of still images through clips of the skills to be taught using (Movie Maker) from the same video clips.

-Then organizing the software to include the introduction of video clips explaining the basic skills (handstand skill handstand rolling on the chest and abdomen - handstand 


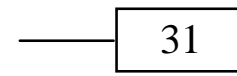

rolling in front) to the computer.

It is represented in the presentation of the introduction, which is that part that is presented without the intervention of the students and includes the title of the study the goal - and the behavioral objectives of the skills, then the technical path for each skill separately, its educational steps and the most important technical points. As the pupils fully control it in terms of choosing the part to be instructed, speed, relay, and exit whenever they want from the program.

A finger-spelling teacher was chosen to accompany the performance by pointing by hand to some of the important requirements for the correct performance of each skill, as well as the method of support, in addition to the performance method, pictures, videos and evaluation questions for each skill.

B- the preparation stage and the Predation: It is represented in:

1- Scriptwriters for the software:

By defining the shape of the main and child windows text and image types, their extension and size. Define the

main browsing style and subtopics - Define how to control the school's means for each frame.

\section{1- Production of means:}

All kinds of media have been prepared using written texts, photographs, audio files with reference, drawings and films, and to ensure their suitability to provide the required information.

3-Preparing auxiliary means:

-Preparing written texts, using (Micro Soft Word) program.

-Preparing audio files: The researcher entered the commentary on the program through the computer's microphone, taking into account that the comment was equal to or less than the viewing time and accompanied by signal movements, lip roll and finger spelling.

-Preparing the video of the skill performance from internet websites and filming one of the players distinguished in the performance of those skills in question.

Use the video card to insert the educational video clips onto the computer.

-The researcher used the "Move Maker" program to divide the educational video tape into several clips and 
select the best video clips to learn the skills in question.

Preparation of photos: The researcher used the "Move Maker" program to divide the video tape into several clips to produce serial still images .

4- Screen design: the researcher was keen on the following

-The screen should not be crowded.

Each screen should contain one activity at most.

Color not to be overused.

-Using sign language and finger-spelling while learning and communicating information.

Then the researcher copies the software on (10) DVDs and adds the explanation and comment by writing on each part so that the performance appears, along with the explanation and commentary on it. Then, the cylinder subject provides programming with some aspects of gymnastics knowledge, research skills, and evaluation questions.

content of the program was presented to a number of (5) experts, including gymnastics professors, to determine the suitability of the content and its applicability to the research sample.

\section{C- Executing phase:}

It is the stage in which the scenario is executed in a programmatic form, so that the students get the software in the CD-ROMs image from the researcher, where he works as soon as he enters the computer. Then the pupils watch it and wander freely within it, then the students practice what they saw in the software under the supervision of the researcher, and in the case of wrong performance, they go to the viewer again and correct the errors.

\section{D- Evaluation phase:}

1- Initial testing of the software:

After completing the preparation of the program on the cylinder, it is presented to a group of experts in the field of teaching methods of gymnastics, Annex (7) to survey their views and determine its suitability for the goals and application.

\section{2- Software Exploratory}

\section{Study:}

The researcher applied the software to a sample of (20) male and female students from outside the research sample, with the aim of knowing the errors and problems that the students fall 
into, and then applying them to the members of the experimental group.

3- Pre measurements:

After conducting scientific transactions of the variables affecting the research, then making pre-measurements in the level of skill performance of the skills under investigation, as well as the level of cognitive achievement of the three skills, in the period from $10 / 10 / 2016$ to 10/15/2016.

Implement the basic experiment:

The researcher applied the educational program (software) in learning some gymnastics skills (handstand handstand, going down on the chest, standing on the hands, and rolling in front) on the experimental group members from 10/16/2016 to 11/30/2016.

The general framework for implementing the program:

The researcher set up 12 study units with two study units each week at a time of (45) minutes, and the best time to implement the program was in the first part of the lesson at the beginning of the lesson, in the warm-up part of the lesson. The optimal time is (before the warm-up), as there is agreement that the agreement ranges between (0-100) in favor of before the warm-up.

\section{Dimensional measurements:}

After the end of the specified period for implementing the proposed program, the researcher applied the dimensional measurements to each of the experimental and control research groups in order to identify the level of skill performance and cognitive achievement as well as to identify the opinions and emotional impressions of the experimental group during the period from $12 / 5 / 2016$ to 12/12/2016.

\section{Statistical processors:}

The researcher used the following statistical treatments: arithmetic mean - median standard deviation - skew coefficient- correlation coefficient - $(\mathrm{T})$ test - T. test alpha coefficient - half segmentation.

Presentation, interpretation and discussion of results:

First: Presentation of results: The researcher will review the research results in the following order: 


\section{Table (3)}

The significance of the differences between the pre and post measurement of the experimental group in the variable of the form of skill performance and the level of cognitive achievement under discussion $\mathrm{N}=\mathbf{1 0}$

\begin{tabular}{|c|c|c|c|c|c|c|c|c|c|c|c|}
\hline \multirow[t]{2}{*}{$\mathbf{s}$} & \multirow[t]{2}{*}{ Variables } & \multicolumn{2}{|c|}{$\begin{array}{c}\text { Pre- } \\
\text { measuremen }\end{array}$} & \multicolumn{2}{|c|}{$\begin{array}{c}\text { Post } \\
\text { measurement }\end{array}$} & \multirow{2}{*}{ Mean } & \multirow{2}{*}{$\begin{array}{l}\text { Standard } \\
\text { error of } \\
\text { the mean }\end{array}$} & \multirow{2}{*}{$\begin{array}{c}\text { Value } \\
(\mathrm{v})\end{array}$} & \multirow{2}{*}{$\begin{array}{c}\% \\
\text { Improvement } \\
\text { rate }\end{array}$} & \multirow{2}{*}{$\begin{array}{c}\text { Effect } \\
\text { size }\end{array}$} & \multirow{2}{*}{$\begin{array}{l}\text { Impact } \\
\text { size } \\
\text { indication }\end{array}$} \\
\hline & & S & $\pm \mathrm{E}$ & S & $\pm \mathrm{E}$ & & & & & & \\
\hline 1 & $\begin{array}{c}\text { Handstand } \\
\text { skill } \\
\end{array}$ & 1.150 & 0.626 & 8.050 & 0.985 & 6.900 & 0.421 & 16.385 & 600.000 & 4.176 & High \\
\hline$r$ & $\begin{array}{l}\text { Handstand } \\
\text { rolling on } \\
\text { chest and } \\
\text { abdomen }\end{array}$ & 1.050 & 0.599 & 8.600 & 0.699 & 7.550 & 0.417 & 18.120 & 719.048 & 5.314 & High \\
\hline$r$ & $\begin{array}{l}\text { Handstand, } \\
\text { roll in front }\end{array}$ & 1.150 & 0.337 & 8.950 & 0.643 & 7.800 & 0.371 & 21.024 & 678.261 & 5.326 & High \\
\hline 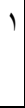 & $\begin{array}{l}\text { Cognitive } \\
\text { achievement }\end{array}$ & 0.900 & 0.658 & 20.500 & 1.581 & 19.600 & 0.591 & 33.183 & 2177.778 & 6.392 & High \\
\hline
\end{tabular}

*Tabular (t) value at $0.05=1.860$ level of significance

Cohen's Effect Volume Levels: 0.20: Low 0.50: Medium 0.80: High

Table (3) shows the significance of the statistical differences at a level of significance 0.05 between the pre and post measurements of the experimental group in the variable of the form of skill performance and the level of cognitive achievement under discussion, and it becomes clear that there are statistically significant differences in favor of the post measurement, where the value of $(\mathrm{T})$ ranged between (16.385 to 33.183) The percentage improvement rates ranged between $(600.00 \%$ to $2177.778 \%$ ), as it is evident from the table that the effect size values for the tests are greater than (0.80) and have achieved values that ranged between (4.176 to 6.392), which are indications of high 0 , which indicates the effectiveness of the proposed program. Big on the dependent variable. 


\section{Table (4)}

The significance of the differences between the pre and post measurement for the control group In the variable form of skill performance and cognitive achievement under discussion $N=10$

\begin{tabular}{|c|c|c|c|c|c|c|c|c|c|c|c|}
\hline \multirow[t]{2}{*}{$\mathrm{S}$} & \multirow[t]{2}{*}{ Variables } & \multicolumn{2}{|c|}{$\begin{array}{c}\text { Pre- } \\
\text { measurement }\end{array}$} & \multicolumn{2}{|c|}{\begin{tabular}{|c|} 
Post \\
measurement
\end{tabular}} & \multirow{2}{*}{$\begin{array}{c}\text { Mean } \\
\text { differences }\end{array}$} & \multirow{2}{*}{\begin{tabular}{|c} 
Standard \\
error of \\
the mean
\end{tabular}} & \multirow{2}{*}{$\begin{array}{c}\text { Value } \\
(\mathbf{v})\end{array}$} & \multirow{2}{*}{\begin{tabular}{|c|}
$\%$ \\
$\begin{array}{c}\text { Improvement } \\
\text { rate }\end{array}$ \\
\end{tabular}} & \multirow{2}{*}{$\begin{array}{c}\text { Effect } \\
\text { size }\end{array}$} & \multirow{2}{*}{\begin{tabular}{|} 
Impact \\
size \\
indication
\end{tabular}} \\
\hline & & $\mathbf{S}$ & $\pm \mathbf{E}$ & $\mathbf{S}$ & $\pm \mathbf{E}$ & & & & & & \\
\hline 1 & Handstand skill & 1.200 & 0.537 & 5.100 & 0.699 & 3.900 & 0.445 & 8.765 & 325.000 & 0.810 & High \\
\hline$r$ & \begin{tabular}{|c|} 
Handstand \\
rolling on chest \\
and abdomen \\
\end{tabular} & 1.000 & 0.408 & 4.700 & 0.632 & 3.700 & 0.403 & 9.171 & 370.000 & 0.730 & Average \\
\hline$r$ & $\begin{array}{l}\text { Handstand, } \\
\text { roll in front }\end{array}$ & 1.100 & 0.394 & 5.100 & 0.843 & 4.000 & 0.368 & 10.864 & 363.636 & 0.883 & High \\
\hline & $\begin{array}{c}\text { Cognitive } \\
\text { achievement }\end{array}$ & 1.000 & 0.667 & 11.900 & 1.524 & 10.900 & 0.493 & 22.110 & 1090.000 & 0.779 & Average \\
\hline
\end{tabular}

*Tabular (t) value at $0.05=1.860$ level of significance Cohen's Effect Volume
The
percentage

Levels: 0.20: Low 0.50: Medium 0.80: High

Table (4) shows the significance of the statistical differences at a level of significance 0.05 between the pre and post measurements of the control group in the variable of the form of skill performance and the attainment and cognitive under consideration.

\section{Table (5)} improvement rates ranged between $(325,000 \%$ to $1090.00 \%$ ), as it is evident from the table that the effect size values for the tests are greater than (0.80) and have achieved values that ranged between $(0.730$ to 0.883$)$, which are high and medium indications 0 , which indicates the effectiveness of the proposed program. Relative to the dependent variable.

The significance of the differences between the mean of the dimensional measurements and the significance of the effect on the variables in the form of skill performance and cognitive achievement of the research, experimental and control groups N $1=$ n $2=10$

\begin{tabular}{c|c|c|c|c|c|c|c|c|c}
\hline \hline \multirow{S}{*}{$\begin{array}{c}\text { Basic } \\
\text { variables }\end{array}$} & $\begin{array}{c}\text { Experimental } \\
\text { group }\end{array}$ & \multicolumn{2}{c|}{$\begin{array}{c}\text { Control } \\
\text { group }\end{array}$} & $\begin{array}{c}\text { The } \\
\text { difference } \\
\text { between the } \\
\text { averages }\end{array}$ & $\begin{array}{c}\text { Value } \\
\text { (v) }\end{array}$ & $\begin{array}{c}\text { Differences } \\
\text { in rates of } \\
\text { improvement }\end{array}$ & $\begin{array}{c}\text { Effect } \\
\text { size }\end{array}$ & $\begin{array}{c}\text { Impact } \\
\text { size } \\
\text { indication }\end{array}$ \\
\hline \hline \hline Handstand skill & 8.050 & 0.985 & 5.100 & 0.699 & 2.950 & 7.725 & 275.000 & 2.995 & High \\
\hline $\begin{array}{c}\text { Handstand } \\
\text { rolling on chest } \\
\text { and abdomen }\end{array}$ & 8.600 & 0.699 & 4.700 & 0.632 & 3.900 & 13.081 & 349.048 & 5.579 & Average \\
\hline $\begin{array}{c}\text { Handstand, } \\
\text { roll in front }\end{array}$ & 8.950 & 0.643 & 5.100 & 0.843 & 3.850 & 11.478 & 314.625 & 5.988 & High \\
\hline $\begin{array}{c}\text { Cognitive } \\
\text { achievement }\end{array}$ & 20.500 & 1.581 & 11.900 & 1.524 & 8.600 & 12.384 & 1087.778 & 5.440 & High \\
\hline \hline
\end{tabular}

The tabular (v) value at the level of 05 significance. $=1.746$ 
Cohen's effect size 13.081), and the differences in levels: 0.20 : low, 0.50 : medium, 0.80: high.

Table (5) shows the significance of the statistical differences between the mean of the dimensional measurements of the two experimental and control groups in the variable of the form of skill performance and the cognitive achievement under study at a significance level of 0.05 , and the value of (T) ranged between $(7.725$ to

\section{Table (6)}

Frequency, percentage, relative weight, and relative importance of emotional opinions and impressions For research sample individuals towards the proposed educational program using interactive video $N=10$

\begin{tabular}{c|c|c|c|c|c|c|c|c}
\hline \hline \multirow{2}{*}{ Phrase } & \multicolumn{2}{|c|}{ Yes } & \multicolumn{2}{c|}{$\begin{array}{c}\text { To some } \\
\text { extent }\end{array}$} & \multicolumn{2}{|c|}{ No } & \multirow{2}{*}{$\begin{array}{c}\text { Relative } \\
\text { weight }\end{array}$} & $\begin{array}{c}\text { Relative } \\
\text { importance }\end{array}$ \\
\cline { 2 - 9 } & $\mathbf{K}$ & $\%$ & $\mathbf{K}$ & $\%$ & $\mathbf{K}$ & $\%$ & & \\
\hline \hline 1 & 9 & 90.000 & 1 & 10.000 & 0 & 0.000 & 29 & 96.667 \\
\hline 2 & 8 & 80.000 & 2 & 20.000 & 0 & 0.000 & 28 & 93.333 \\
\hline 3 & 10 & 100.000 & 0 & 0.000 & 0 & 0.000 & 30 & 100.000 \\
\hline 4 & 7 & 70.000 & 3 & 30.000 & 0 & 0.000 & 27 & 90.000 \\
\hline-5 & 0 & 0.000 & 1 & 10.000 & 9 & 90.000 & 29 & 96.667 \\
\hline 6 & 10 & 100.000 & 0 & 0.000 & 0 & 0.000 & 30 & 100.000 \\
\hline 7 & 9 & 90.000 & 1 & 10.000 & 0 & 0.000 & 29 & 96.667 \\
\hline-8 & 0 & 0.000 & 0 & 0.000 & 10 & 100.000 & 30 & 100.000 \\
\hline 9 & 10 & 100.000 & 0 & 0.000 & 0 & 0.000 & 30 & 100.000 \\
\hline-10 & 0 & 0.000 & 1 & 10.000 & 9 & 90.000 & 29 & 96.667 \\
\hline 11 & 9 & 90.000 & 1 & 10.000 & 0 & 0.000 & 29 & 96.667 \\
\hline 12 & 10 & 100.000 & 0 & 0.000 & 0 & 0.000 & 30 & 100.000 \\
\hline 13 & 10 & 100.000 & 0 & 0.000 & 0 & 0.000 & 30 & 100.000 \\
\hline 14 & 9 & 90.000 & 1 & 10.000 & 0 & 0.000 & 29 & 96.667 \\
\hline 15 & 9 & 90.000 & 1 & 10.000 & 0 & 0.000 & 29 & 96.667 \\
\hline \hline
\end{tabular}


Table (6) shows the frequency, percentage, relative weight, and the relative importance of the emotional opinions and impressions of the individuals of the research sample towards the proposed educational program using the interactive video, and the percentage ranged between (90,000\% - $100.00 \%)$

Second: Discussing the results:

Table (3) shows that there are statistically significant differences (0.05) amounting to 1.860 , as the effect size levels for Cohil ranged between (0.20), low (0.50), medium and (0.80) high, indicating the existence of statistically significant differences in the form of skill performance.

For the skills under investigation in favor of measurement, as well as the level of cognitive achievement, and the dimension in which it ranged between (16.385 to 33.183 ), as well as the presence of statistically significant differences from the level of significance $(0.05)$ in the rate of change (percentage improvement) in the level of skill performance and cognitive achievement.
Between $\quad(600.00 \%$ to $2177.7 \%$ ), it is evident that the effect size values are greater than (80\%), which are high indications indicating the effectiveness of the proposed program and the positive impact of the interactive video program when performing the learning of some gymnastics skills for deaf and dumb students, as well as the amount of information that is used Including students by making use of educational aids, pictures and drawings in communicating information in an interesting, attractive and easy way, and taking advantage of technology in delivering better educational environments for students, as in studying both Abdel Karim (2005), Al Shahat (2003). Aristes Cojar Bravo (2010)

The researcher attributes the existence of these differences to the effect of using interactive video, from which more than one method emerges from it to learn some gymnastics skills for deaf and dumb pupils. Sight is an important element of communication to acquire information and knowledge, as Abd al-Ghaffar (2003) emphasizes that the sense of vision helps deaf and dumb 
pupils to perceive and understand what surrounds and what is going on around them. Understanding and communicating information. There is no doubt that there will be technological means (interactive video) through which the sound and image are displayed through a display screen, working as one integrated unit, with accompanying translation into sign language to increase the clarity of performance, which leads to the speed of learning and mastery of the skills in question, and the acquisition of information and knowledge of those

The category we find that the interactive video program is characterized by a good presentation method that attracts that category to learn. The use of technology made the learner learn by himself and walk in the educational process according to his own speed and love in dealing with the computer, which has become evident in the state's preparation of programs on this device translated into sign language To facilitate communication between the deaf and others, and we find that there is a great development in the use of that category of the deaf and the dumb for the computer, as it can be said that the deaf found in this device their way. At school gymnastics subject.

Sweidan and El-Jazzar (2007) also indicate that learning technology has a great role in improving teaching and learning for people with special needs, as it raises interest in learning and helps in overcoming the verbal problem.

Thus, the first objective is validated, which states: "There are statistically significant hypotheses between the averages of the pre and post measurements of the experimental group in the level of skill performance and the cognitive achievement of the skills under investigation in favor of the post measurement".

Table (4) shows that there are statistically significant differences between the pre and post measurements of the control group in the variable of the form of skill performance and cognitive achievement in favor of the post measurement. Where the table $(\mathrm{t})$ value was at the level of significance $(0.05)=1.860$, and it increased to the value between (8.765 to 22.110). 
It was also increased until the improvement ratios between (325.00\% to 1090.00 ) and thus the effect size value for the tests was greater than $(0.80 \%)$ It ranged from $(0.730$ to 0.883 ), and this is a high indication, indicating the effectiveness of the program in a high manner, but at a lower rate than the proposed program in learning the experimental group.

We find an improvement in the control group to which the traditional program is applied, and this shows that the traditional method has an effect in addition to what the teacher follows while teaching those skills by giving a clear idea through the model and accompanying the explanation in the language of the sign or the movement of the lips, which helps to teach easy. This is consistent with Mahmoud (2012) and Abdel-Hamid (2014) study.

In this way, it achieves the validity of the second objective, which states "there are statistically significant differences between the averages of the pre and post measurements of the control group in the level of skill performance and the cognitive achievement of the skills under investigation in favor of the post measurement".

Table (5) shows that there is a statistical significance between the averages of the dimensional measurements for each of the experimental and control group in favor of the experimental group in both the level of the skill performance form of the skills under investigation as well as the cognitive achievement at the level of 0.05 significance and the value of $(\mathrm{t})$ ranged between (7.72 to 13.081 The differences in the significant improvement rates ranged between $(275.00 \%$ to 349.0), and the effect size values between the experimental and control groups were greater than $0.80 \%$, and they ranged from (2.995 - 5.988), which are high indications indicating the effectiveness of the program is higher on those variables in favor of the group. The experimental group, with a large difference from the control group that uses traditional methods of completing the educational process in that category

The researcher attributes the superiority of the experimental group over the control group in the level of skill performance 
of the skills in question to the use of the interactive video method, because of the interactive video that takes into account the level, capabilities and needs of that group of learners through the accurate presentation of the parts of the skills in an interesting way and accompanied by translation in sign language and spelling of the lips.

This led to an improvement in the level of skill performance, as Aristides Gajar (2010) indicates that interactive video is more effective than the methods used and helps to support selfdirection and speed of learning. This is consistent with the study of both Al-Fathli (2013) and Abdul-Hamid (2014), whose study confirmed that dividing the educational position leads to an increase in the chances of success, a reduction in the wrong response, an increase in positivity towards participation in performance according to their speed and abilities, and an attempt to reach better performance and self-reliance and through

The interaction of the pupils with the programming prepared in the style of interactive video and knowing how to operate it and calling serial pictures, special videos and texts accompanied by sign language all of this helped the pupils to speed up and find learning and the presence of an attractive educational climate as all students find using the computer, especially as it is equipped with sign language programs, which prompted the researcher to know Watching each skill under discussion, as well as the signals that translate the skillful performance of deaf and dumb pupils, serial images, text and video that are displayed through the normal display, slow display and enlargement of each skill separately and in different and attractive colors, make presenting these skills as an integrated unit, and all this is a work for students to accept The educational process is easy and easy, thus increasing the effectiveness and speed of learning.

In this way, the third objective is valid, which states: "There are significant statistical differences between the two dimensional measures of the experimental and control group in both the level of skill performance and cognitive achievement in favor of the experimental group". 
Table (5) and (6) show that there are statistically significant differences between the mean of the two dimensional measures of the experimental and control groups in the level of cognitive achievement.

The researcher attributes this progress to the use of interactive video, which has a positive impact on achievement, a storage system and display of visual information, and the movement of students from step to step according to their abilities and individual differences.

As for the emotional opinions and impressions of the pupils, which are shown in Table (18) about the program in learning some gymnastics skills, it is clear from the table that the percentages ranged between $90 \%$ to $100 \%$, which led to the fact that the program used led to attracting the attention of the learners and this is confirmed by Aristides ( 2010) who emphasized that the use of interactive video is easier and better due to its interaction with many data, and this is consistent with the study of Al-Najjar and Atallah (2003), Abdul-Muqtadir (2012), Al-Tahli (2013), and Abdel-Hamid (2014), thus achieving the validity of the fourth purpose which states that "There are statistically significant differences between the pre and post measurements of the experimental group towards the use of the interactive video tutorial in learning the skills under investigation in favor of the post measurement".

Conclusions and recommendations: Conclusions:

In light of the study's objectives and hypotheses, the following conclusions were reached:

1- $\quad$ The proposed educational program using the interactive video contributed positively to improving the skill level of the skills under discussion (handstand skill - handstand skill, rolling on the chest and abdomen - handstand skill, front rolling for deaf and dumb students, as well as the level of cognitive achievement.

2- The proposed educational program using the interactive video contributed positively to the opinions and impressions of deaf and dumb pupils towards learning the skills under consideration in particular and gymnastics in general.

3- The traditional program. Explanation and performance 
of the model using sign language and finger-spelling led to the learning of the skills in question, which led to an improvement in the level of skill performance and cognitive achievement.

\section{Recommendations:}

1- Using interactive video software when performing some gymnastics skills for deaf and dumb students.

2- Training teachers on how to use the interactive video software in the learning of deaf and dumb pupils.

3- $\quad$ Raising the level of deaf and dumb pupils in interacting with technological means by providing many technological devices .

\section{Refrenace:}

1-Abdel Aal, Hani Ahmed. (2007): The effectiveness of using some signal-supported technology means on the level of performance of some basic basketball skills for deaf and dumb pupils. Unpublished $\mathrm{PhD}$ thesis. College of Physical Education for Boys. Zagazig University.

\section{2-Abdul Ghaffar, Rajab}

Dreams. (2003): Educational care for the deaf, dumb and hard of hearing. Cairo: Dar AlFajr for Publishing and Distribution.
3- Abdel-Hamid, Abdulaziz Students. (2010): E-learning and educational technology developments. Cairo: The Modern Library.

4- Abdel Hamid, Tamer Ibrahim. (2014): The effect of multimedia use on the level of performance of some basic handball skills among deaf and dumb pupils. A magister message that is not published. Faculty of Physical Education. Tanta University.

\section{5- Abdul Karim, Bassem} Mahmoud. (2005): The effectiveness of a proposed program using interactive and written videos to learn some physical education lessons for students of the second stage of basic education. Unpublished $\mathrm{PhD}$ thesis. Faculty of Physical Education. Minia University.

6-Abdul Shakour, Ghaida and Roshdy, Saudi Arabia (2009): The effectiveness of a program using some supermedia on some physical and psychological variables, the level of skill performance and cognitive achievement in gymnastics. Sports (Science and Arts). Mag 34, Vol 2, Egypt.

7-Al-Thaqafi, Nayef. (2012): The effectiveness of a computer program in improving some academic 
skills of children with hearing impairment. A magister message that is not published. Faculty of Education. AinShams University.

\section{8-Al-Fathli, Rabia Al-} Mabrouk, Suez. (2013): The effect of using visual teaching aids on learning aspects of the long jump skill for deaf and dumb pupils. Unpublished $\mathrm{PhD}$ thesis. College of Education for Boys. Alexandria University.

9-Al-Najjar, Hisham Muhammad and Attallah, Yahya Ahmad. (2003): the effect of using a computer program in the educational part of the physical education course on learning some gymnastics skills among deaf and dumb pupils. Published research. Physical Education Journal.

10-Al-Shetati, Effat Awad Ahmed. (2005): The effect of a sports health program on the health behavior of the deaf and dumb. A magister message that is not published. Faculty of Physical Education. Tanta University.

\section{1-Ali, Muhammad Al-} Sayed. (2009): Educational technology and educational aids. Tanta: Al Israa Library House for Publishing and Distribution.

\section{2-And Tut, Hamdi Ahmad and Sawwaf, Noha Mahmoud}

Al Sawaf. (2013): The deaf and merging with the normal in physical education and sports. Cairo: Book Center for Publishing.

\section{3-Aristides Cajar Bravo,} B.A, M.B.AM.A.(2010): Expanding learning and teaching processes in an Esl/cirics ABE classroom using an inter ctirevideo lesson plan in the U-s south west for the degree Doctor of phifosophy New Mexice state unirersity las crucer New Mexico .

14-Browmson et al. (2007): The Effect of disseminating evidence based in tarnation that promote physical activity to heath departments, AML, Pubic Health, Aug.

15-Cardener David .(2003): Evaluating user interactive videouser's perceptions of self. Access language. Learning with multimedia movies (china) open University united Knitted.

16-Farhat, Lily. (2003): Measurement and testing in physical education. Cairo: Book Center for Publishing.

17-Fenstermacher, K. M. (2001): An interactive, computer-based social skills training program: development and use with children with attention deficit hyperactivity 


\section{4}

disorder (pp. 1-158). The University of Utah.

18-Ibrahim, Ola Abdel-Al. (2010). The effectiveness of the two methods of multi-level self-application and guided discovery on learning some gymnastics skills for first stage students of basic education. A magister message that is not published. Faculty of Physical Education. Tanta University.

19-Ismail, Magda and others. (2006). The effect of an educational program for some gymnastics skills using hypermedia on the learning aspects of the elementary squad students. Journal of Mathematical Sciences and Arts. College of Physical Education for Girls in Cairo. Helwan University.

20 - Isn, Rida Saad. (2008). The effect of a proposed educational program using the computer on the aspects of learning the skill of rolling, background, and handstand among female students of the Mathematical College of Tanta University. The Fourth Regional Conference of the International Council for Health, Physical Education and Recreation 15-17 October 2008 at the College of Physical Education for Boys.
Alexandria University in $\mathrm{Abu}$ Kir.

\section{1-Mazen, Hussam Al-Din} Muhammad. (2009).

Educational technology and education quality assurance. Cairo: Dar Al-Fajr for Publishing and Distribution.

22-Mahmoud, Iman Abdel Moqtader. (2005). The effect of a proposed educational program using optical images on aspects of volleyball learning among deaf and dumb pupils. A magister message that is not published. Faculty of Physical Education. Tanta University

23-Mahmoud, Iman Abdel Moqtader. (2012). Building an educational program on the international information network and its impact on the aspects of learning some volleyball skills for students of the second stage of basic education. Unpublished $\mathrm{PhD}$ thesis. Faculty of Physical Education. Tanta University.

24-Mahmoud, Muhammad Saad Zaghloul and Mahrous, Lamia Fawzi. (2002). An educational program using educational media on aspects of learning in basketball for second stage pupils of basic education. The Scientific Journal of Physical Education. College of Physical Education 


\section{5}

for Girls. Alexandria University.

25-Muhammad, Khadra Eid and Hijazi, Hala Yahya. (2011). The effect of a recreational exercise program on the degree of performance of some gymnastic floor movements, the level of motor fitness and some social skills of a preschooler. Published research. Journal of the First International Scientific Conference on Sport and Childhood. Faculty of Physical Education. P 1. October.

26-Nazmi, Ahmad Muhammad. (2008). The effect of using computers on learning some basic handball skills for deaf and dumb students. A magister message that is not published. Faculty of Physical Education, Sadat. al-manoufia University. 27-Salama, Ibrahim Ahmed. (2000). Application portal to measure fitness. Alexandria: House of Knowledge.

28-Shenouda, Idil Saad and Farghali, Samia. (1999). Artistic Gymnastics "Concepts - Applications". Alexandria: a meeting place for thought.
29-Shahat, Muhammad Rajab. (2003). the effectiveness of using an interactive video program in developing the basic skills needed to operate and maintain some educational devices among educational technology students. A magister message that is not published. Institute for Research Studies. Cairo University.

30-Shehata, Muhammad Ibrahim and Abd al-Salam, Muhammad (1991). Foundations of hardware gymnastics. Alexandria: El-Tony Press.

31-Shehata, Muhammad Ibrahim. (2003). Foundations of gymnastics education. Cairo: The Arab Thought House.

32-Shukair, Zainab Mahmoud. (2005). I am your son who is handicapped in mind, hearing and vision (2nd ed.), Cairo: The Egyptian Renaissance Library.

33-Sweidan, Amal AbdelFattah and El-Jazzar, Mona Al-Safi. (2007). The Use of Technology in Special Education, Cairo: The Book Center for Publishing. 